\title{
Prediction of lean body mass from height and weight
}

\author{
R. HUME \\ From the Department of Medicine, Southern General Hospital, Glasgow
}

SYNOPSIS Lean body mass, calculated from the measurement of total body water using antipyrine space, was estimated in 29 males and 27 females. It was found that the lean body mass could be predicted from the height and weight, and formulae for both males and females have been produced with multiple correlation coefficients (r) of 0.96 and 0.83 respectively.

In 1956 Allen, Peng, Chen, Huang, Chang, and Fang showed that the circulating total blood volume was closely related to a combination of body weight and cube of height. In 1962 Nadler, Hidalgo, and Bloch improved on this formula by adding a computer correction factor. Since the red cell volume is directly related to the lean body mass or fat-free body weight (Muldowney, 1957), and since the red cell volume derived from the height-cubed body weight formula of Nadler, Hidalgo, and Bloch correlates closely with the red cell volume derived from the lean body mass relationship (Hume and Goldberg, 1964), it seemed likely that the lean body mass could be predicted from height and weight. In 1965, Steinkamp, Cohen, Goffey, McKey, Bron, Siri, Sargent, and Isaacs showed from an extensive study of the problem that fat weight could be accurately predicted from body parameters other than height and weight. This paper presents evidence which confirms the practicability of predicting lean body mass from height and weight.

\section{METHODS}

CLINICAL CASES Fifty-six subjects were studied (29 males and 27 females). They comprised four main clinical groups: those with no apparent disorder, those suffering

\section{TABLE I}

GENERAL DESCRIPTION OF SUBJECTS STUDIED

\begin{tabular}{|c|c|c|c|c|}
\hline \multirow[t]{2}{*}{ Group } & \multicolumn{2}{|l|}{ Males } & \multicolumn{2}{|l|}{ Females } \\
\hline & $\begin{array}{l}\text { No. of } \\
\text { Subjects }\end{array}$ & $\begin{array}{l}\text { Mean Age } \\
(y r .)\end{array}$ & $\begin{array}{l}\text { No. of } \\
\text { Subjects }\end{array}$ & $\begin{array}{l}\text { Mean Age } \\
(y r .)\end{array}$ \\
\hline
\end{tabular}

$$
\begin{aligned}
& \text { Nor } \\
& \text { Poly } \\
& \text { ver } \\
& \text { Total } \\
& \text { Rece } \\
& 8
\end{aligned}
$$


TABLE III

RESULTS IN FEMALES

\begin{tabular}{|c|c|c|c|c|}
\hline Case No. & $\begin{array}{l}\text { Age } \\
(y r .)\end{array}$ & $\begin{array}{l}\text { Height } \\
(\mathrm{cm} .)\end{array}$ & $\begin{array}{l}\text { Total Body } \\
\text { Weight } \\
\text { (kg.) }\end{array}$ & $\begin{array}{l}\text { Lean Body } \\
\text { Mass } \\
\text { (kg.) }\end{array}$ \\
\hline 1 & 48 & $160 \cdot 0$ & $64 \cdot 4$ & $37 \cdot 0$ \\
\hline 2 & 56 & $139 \cdot 7$ & 54.0 & $32 \cdot 2$ \\
\hline 3 & 65 & $161 \cdot 3$ & $63 \cdot 1$ & $48 \cdot 2$ \\
\hline 4 & 58 & 160.0 & $67 \cdot 2$ & $39 \cdot 5$ \\
\hline 5 & 80 & 152.4 & 48.6 & $43 \cdot 9$ \\
\hline 6 & 69 & $152 \cdot 4$ & 59.4 & $41 \cdot 9$ \\
\hline 7 & 70 & 152.4 & $67 \cdot 2$ & $31 \cdot 3$ \\
\hline 8 & 66 & 160.0 & 56.7 & $28 \cdot 4$ \\
\hline 9 & 69 & 152.4 & $69 \cdot 4$ & $41 \cdot 8$ \\
\hline 10 & 55 & 156.2 & 59.0 & 34.0 \\
\hline 11 & 59 & $160 \cdot 0$ & $81 \cdot 2$ & $46 \cdot 8$ \\
\hline 12 & 37 & $158 \cdot 8$ & $115 \cdot 5$ & $59 \cdot 3$ \\
\hline 13 & 62 & $157 \cdot 5$ & $106 \cdot 2$ & $55 \cdot 3$ \\
\hline 14 & 55 & 152.4 & $97 \cdot 6$ & 50.9 \\
\hline 15 & 52 & 154.9 & 92.6 & 43.4 \\
\hline 16 & 52 & 155.6 & 97.6 & $54 \cdot 8$ \\
\hline 17 & 51 & $144 \cdot 8$ & $45 \cdot 8$ & 38.0 \\
\hline 18 & 54 & $172 \cdot 8$ & 83.0 & 51.0 \\
\hline 19 & 62 & $160 \cdot 0$ & $48 \cdot 3$ & $38 \cdot 2$ \\
\hline 20 & 67 & $151 \cdot 0$ & $47 \cdot 0$ & 31.0 \\
\hline 21 & 65 & 160.0 & $63 \cdot 5$ & 47.0 \\
\hline 22 & 71 & $147 \cdot 3$ & $56 \cdot 3$ & $35 \cdot 2$ \\
\hline 23 & 64 & 154.9 & $65 \cdot 8$ & $44 \cdot 6$ \\
\hline 24 & 69 & $157 \cdot 5$ & $52 \cdot 2$ & $34 \cdot 8$ \\
\hline 25 & 60 & 182.9 & $69 \cdot 9$ & 62.5 \\
\hline 26 & 48 & 162.6 & $71 \cdot 4$ & $41 \cdot 6$ \\
\hline 27 & 57 & $139 \cdot 7$ & $44 \cdot 7$ & $29 \cdot 1$ \\
\hline
\end{tabular}

${ }^{1}$ Lean body mass derived from measurement of total body water

Patients with a spinal deformity were excluded. The total body weight in kilograms was estimated after outdoor clothes only had been removed in order to make the procedure readily applicable to out-patients.

LEAN BODY MASS (Tables II and III) Antipyrine space was measured by the method described by Muldowney (1957). 'Lean body mass' was calculated from the antipyrine space by the equation of Pace and Rathbun (1945).

\section{RESULTS}

MALES (29) The linear regression of lean body mass (L.B.M.) in $\mathrm{kg}$. on weight (W) in $\mathrm{kg}$. and on height (H) in $\mathrm{cm}$. is:-

$$
\text { L.B.M. }=0.32810 \mathrm{~W}+0.33929 \mathrm{H}-29.5336
$$

The correlation coefficient ( $\mathrm{r}$ ) between $\mathrm{H}$ and $\mathrm{W}$ was 0.3744 and between $\mathrm{H}$ and L.B.M. was 0.6719 and between $\mathrm{W}$ and L.B.M. was $\mathbf{0} \cdot 8840$, yielding a multiple correlation coefficient (r) between L.B.M. and $\mathrm{H}$ and $\mathrm{W}$ of 0.957 . The standard deviation of deviations from regression is $2.307 \mathrm{~kg}$.

Using $(\mathbf{H})^{3}$ instead of $\mathbf{H}$ gave the following linear regression:-

$$
\text { L.B.M. }=0.33103 \mathrm{~W}+0.0000039726(\mathrm{H})^{3}
$$

which gave the following coefficients: $(\mathrm{H})^{3}$ and $\mathrm{W}$, $\mathrm{r}=0.3477,(\mathrm{H})^{3}$ and L.B.M., $\mathrm{r}=0.6660, \mathrm{~W}$ and L.B.M., $r=0.8840$. The first two correlations in equation 2 are slightly inferior to the correlations of equation 1 and therefore for the range of heights weights, and lean body masses in the present study. equation 1 is the more suitable.

FEMALES (27) The linear regression of L.B.M. (kgq on weight $(\mathrm{W})$ in $\mathrm{kg}$. and on height $(\mathrm{H})$ in $\mathrm{cm}$. is :L.B.M. $=0.29569 \mathrm{~W}+0.41813 \mathrm{H}-43.2933$

(equation 19

The correlation coefficients (r) between $\mathrm{H}$ and was 0.3098 and between $\mathrm{H}$ and L.B.M. was 0.5877 and between $\mathrm{W}$ and L.B.M. was 0.7390 , yielding a multiple correlation coefficient $r$ between L.B.M and $\mathrm{H}$ and $\mathrm{W}$ of $\mathbf{0 . 8 2 9 8}$. The standard deviation $\mathrm{O}$ deviations from regression is $5 \cdot 372 \mathrm{~kg}$.

Using $(\mathrm{H})^{3}$ instead of $\mathrm{H}$ gave the following lineäb regression:-

L.B.M. $=0.29873 \mathrm{~W}+0.0000056477(\mathrm{H})^{3}+0.08$ (equation 29 which gave the following coefficients: $(\mathrm{H})^{3}$ and $r=0.2815$ and $(\mathrm{H})^{3}$ and L.B.M., $r=0.5886$. As with the males, equation 2, using height cubee has no advantage over equation 1 .

\section{DISCUSSION}

Analysis shows that the lean body mass or fat-fre body weight obtained by measuring total body wate bears a close correlation with height and weight both males $(r=0.96)$ and females $(r=0.83)$. Sin the cube of height makes a greater contribution than height alone to the prediction of total blood volume (Allen et al., 1956; Nadler et al., 1962) and since red cell volume is clearly related to lean body mass (Muldowney, 1957), it is of interest that analysis failed to show any advantage in using height cubed in the prediction of lean body mass.

Tables for easy calculation of the lean body mass from height and weight are produced (Tables IV an V). The standard deviation of deviations from regreșsion for the males is $2.3 \mathrm{~kg}$. which is an acceptable margin of error in making a prediction of lean bod mass. In female subjects, the standard deviation $\underset{\Psi}{ }$ deviations from regression of $5.4 \mathrm{~kg}$. may be a litthe large for individual prediction but it is satisfactofy when comparing groups of individuals. Moore Olesen, McMurray, Parker, Ball, and Boyden (1963) have shown that the total body water contribute less to the total body weight of men over the age 60 than to those between 16 and 60 years of age Although a number of the men studied were over the age of 60 years there seems no benefit in introducing another variable in the analysis since the correlation of lean body mass to height and weight is so close to unity $(r=0.96)$. Therefore the formula is applio able to males over the age of 16 years. Moore et have also shown that in females over 30 age has no 
TABLE IV

TABLE OF PREDICTED LEAN BODY MASS IN MEN

\begin{tabular}{|c|c|c|c|c|c|c|c|c|}
\hline \multirow{2}{*}{$\begin{array}{l}\text { Weight } \\
\text { (kg.) }\end{array}$} & \multicolumn{8}{|c|}{ Height (cm.) } \\
\hline & 150 & 155 & 160 & 165 & 170 & 175 & 180 & 185 \\
\hline 45 & $36 \cdot 12$ & $37 \cdot 82$ & $39 \cdot 52$ & $41 \cdot 21$ & 42.91 & $44 \cdot 61$ & $46 \cdot 30$ & $48 \cdot 00$ \\
\hline 50 & $37 \cdot 76$ & $39 \cdot 46$ & $41 \cdot 16$ & 42.85 & $44 \cdot 55$ & $46 \cdot 25$ & 47.94 & $49 \cdot 64$ \\
\hline 55 & $39 \cdot 40$ & $41 \cdot 10$ & $42 \cdot 80$ & 44.49 & $46 \cdot 19$ & $47 \cdot 89$ & $49 \cdot 58$ & $51 \cdot 28$ \\
\hline 60 & 41.05 & $42 \cdot 75$ & 44.45 & $46 \cdot 14$ & $47 \cdot 84$ & $49 \cdot 54$ & $51 \cdot 23$ & 52.93 \\
\hline 65 & 42.69 & $44 \cdot 39$ & 46.09 & $47 \cdot 78$ & $49 \cdot 48$ & $51 \cdot 18$ & $52 \cdot 87$ & $54 \cdot 57$ \\
\hline 70 & $44 \cdot 33$ & 46.03 & $47 \cdot 73$ & $49 \cdot 42$ & $51 \cdot 12$ & 52.82 & $54 \cdot 51$ & $56 \cdot 21$ \\
\hline 75 & 45.97 & 47.67 & $49 \cdot 37$ & 51.06 & $52 \cdot 76$ & $54 \cdot 46$ & $56 \cdot 15$ & $57 \cdot 85$ \\
\hline 80 & $47 \cdot 61$ & $49 \cdot 31$ & 51.01 & $52 \cdot 70$ & $54 \cdot 40$ & $56 \cdot 10$ & $57 \cdot 79$ & 59.49 \\
\hline 85 & $49 \cdot 25$ & 50.95 & 52.65 & $54 \cdot 34$ & 56.04 & $57 \cdot 74$ & $59 \cdot 43$ & $61 \cdot 13$ \\
\hline 90 & 50.89 & 52.59 & $54 \cdot 29$ & 55.98 & 57.68 & $59 \cdot 38$ & $61 \cdot 07$ & $62 \cdot 77$ \\
\hline 95 & 52.53 & $54 \cdot 23$ & 55.93 & $57 \cdot 62$ & $59 \cdot 32$ & 61.02 & $62 \cdot 71$ & $64 \cdot 41$ \\
\hline 100 & $54 \cdot 17$ & $56 \cdot 17$ & $57 \cdot 57$ & $59 \cdot 26$ & 60.96 & 62.66 & $64 \cdot 35$ & 66.05 \\
\hline 105 & $55 \cdot 81$ & $57 \cdot 81$ & $59 \cdot 21$ & 60.90 & 62.60 & $64 \cdot 30$ & 65.99 & 67.69 \\
\hline 110 & $57 \cdot 45$ & $59 \cdot 45$ & $60 \cdot 85$ & $62 \cdot 54$ & $64 \cdot 24$ & 65.94 & 67.63 & $69 \cdot 33$ \\
\hline 115 & 59.09 & 61.09 & 62.49 & $64 \cdot 18$ & $65 \cdot 88$ & $67 \cdot 58$ & $69 \cdot 27$ & 70.97 \\
\hline 120 & $60 \cdot 73$ & $62 \cdot 73$ & $64 \cdot 13$ & $65 \cdot 82$ & $67 \cdot 52$ & $69 \cdot 22$ & 70.91 & $72 \cdot 61$ \\
\hline 125 & $62 \cdot 37$ & $64 \cdot 37$ & $65 \cdot 77$ & $67 \cdot 46$ & $69 \cdot 16$ & $70 \cdot 86$ & $72 \cdot 55$ & $74 \cdot 25$ \\
\hline 130 & $64 \cdot 01$ & 66.01 & $67 \cdot 41$ & $69 \cdot 10$ & $70 \cdot 80$ & $72 \cdot 50$ & $74 \cdot 19$ & $75 \cdot 89$ \\
\hline 135 & 65.65 & 67.65 & 69.05 & $70 \cdot 74$ & $72 \cdot 44$ & $74 \cdot 14$ & 75.83 & $77 \cdot 53$ \\
\hline 140 & $67 \cdot 29$ & $69 \cdot 29$ & 70.69 & $72 \cdot 38$ & 74.08 & $75 \cdot 78$ & $77 \cdot 47$ & $79 \cdot 17$ \\
\hline
\end{tabular}

(L.B.M. $=0.32810 \mathrm{~W}+0.33929 \mathrm{H}-29.5336)$

\section{TABLE V}

TABLE OF PREDICTED LEAN BODY MASS IN WOMEN

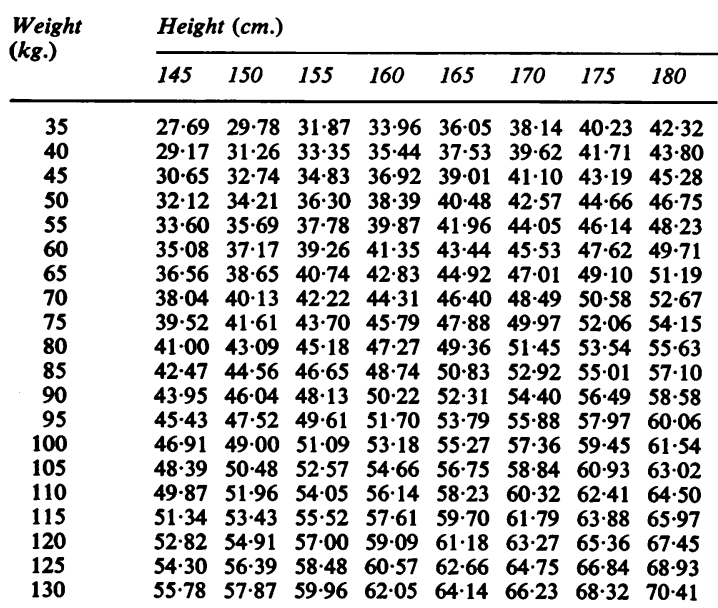

(L.B.M. $=0.29569 \mathrm{~W}+0.41813 \mathrm{H}-43.2933$ ) effect in relation to total body water although it does have in those below 30. Since the youngest woman studied in this series was 37 , it is suggested that the formula is probably only applicable to those over the age of 30 years.

Although many of the subjects studied were selected because of particular clinical problems (Table I), nevertheless they were unselected with regard to height and, with the exception of nine obese patients, to weight. They may therefore in all probability be regarded as a random sample of a hospital population and it is suggested that the formulae are applicable to hospital patients. It is recognized that this recommendation is contrary to the opinion of Edwards and Whyte (1962), who concluded from their own observations and after reviewing the literature, that there was no method for estimating at all accurately the fat mass (calculated from total body water) from simple accessible bodily measurements. But, in the construction of their formulae, they failed to differentiate between the sexes. This may well have been important since not only is age a factor but total body water related to body weight is different between the sexes (Moore et al., 1963).

I am indebted to Dr. R. A. Robb, Mitchell Lecturer in Statistics, University of Glasgow, for the statistical analysis. I am also grateful to Professor Sir Edward Wayne, University Department of Medieine, Western Infirmary, Glasgow, for providing facilities to carry out this study, and to Dr. L. D. W. Scott, senior physician, Southern General Hospital, Glasgow, for helpful advice in the preparation of the paper.

\section{REFERENCES}

Allen, T. H., Peng, M. T., Chen, K. P., Huang, T. F., Chang, C., and Fang, H. S. (1956). Metabolism, 5, 328.

Edwards, K. D. G., and Whyte, H. M. (1962). Clin. Sci., 22, 347.

Hume, R., and Goldberg, A. (1964). Ibid., 26, 499.

Moore, F. D., Olesen, K. H., McMurray, J. D., Parker, H. V., Ball, M. R., and Boyden, C. M. (1963). The Body Cell Mass and Its Supporting Environment. Saunders, Philadelphia, London.

Muldowney, F. P. (1957). Clin. Sci., 16, 163.

Nadler, S. B., Hidalgo, J. U., and Bloch, T. (1962). Surgery, 51, 224

Pace, N., and Rathbun, E. H. (1945). J. biol. Chem., 158, 685.

Steinkamp, R. C., Cohen, N. L., Goffey, W. R., McKey, T., Bron, G., Siri, W. E., Sargent, T. W., and Isaacs, E. (1965). J. chron. Dis., 18, 1291. 